This item was submitted to Loughborough's Research Repository by the author.

Items in Figshare are protected by copyright, with all rights reserved, unless otherwise indicated.

\title{
Spillovers from the oil sector to the housing market cycle
}

PLEASE CITE THE PUBLISHED VERSION

http://dx.doi.org/10.1016/j.eneco.2016.11.004

\section{PUBLISHER}

(C) Elsevier

\section{VERSION}

AM (Accepted Manuscript)

\section{PUBLISHER STATEMENT}

This work is made available according to the conditions of the Creative Commons Attribution-NonCommercialNoDerivatives 4.0 International (CC BY-NC-ND 4.0) licence. Full details of this licence are available at: https://creativecommons.org/licenses/by-nc-nd/4.0/

\section{LICENCE}

CC BY-NC-ND 4.0

\section{REPOSITORY RECORD}

Agnello, Luca, Vitor Castro, Shawkat Hammoudeh, and Ricardo M. Sousa. 2019. "Spillovers from the Oil Sector to the Housing Market Cycle". figshare. https://hdl.handle.net/2134/24129. 


\title{
Spillovers from the Oil Sector
}

\section{to the Housing Market Cycle*}

\author{
Luca Agnello ${ }^{\dagger}$ \\ University of Palermo
}

\author{
Vitor Castro ${ }^{\ddagger}$ \\ University of Coimbra and NIPE
}

\author{
Shawkat Hammoudeh ${ }^{\S}$ \\ Drexel University and IPAG Business School \\ Ricardo M. Sousa \\ University of Minho, NIPE and London School of Economics
}

\begin{abstract}
We assess the spillovers from the oil sector to the housing market cycle using quarterly data for 20 net oil exporting and importing industrial countries, and employing continuous- and discrete-time duration models. We do not uncover a statistically significant difference in the average duration of booms and normal times in the housing markets of those net oil importers and net oil exporters. Similarly, the degree of exposure to commodity price fluctuations does not seem to significantly affect the housing market cycle. However, we find that housing booms are shorter when oil prices increase. We also show that net oil importers are more vulnerable to protracted housing slump episodes than net oil exporters.

Keywords: housing booms and busts, normal times, duration analysis, oil prices.
\end{abstract}

JEL Classification: C41, E32, E51, E52.

${ }^{*}$ Castro and Sousa acknowledge that this work has been financed by Operational Programme for Competitiveness Factors - COMPETE and by National Funds through the FCT - Portuguese Foundation for Science and Technology within the remit of the project "FCOMP-01-0124-FEDER-037268 (PEst-C/EGE/UI3182/2013)". Castro also wishes to thank the financial support provided by the Portuguese Foundation for Science and Technology under the research grant SFRH/BSAB/113588/2015 (partially funded by COMPETE, QREN and FEDER).

†University of Palermo, Department of Economics, Business and Statistics (SEAS), Viale delle Scienze, 90128 Palermo, Italy. Email: luca.agnello01@unipa.it.

$\ddagger$ University of Coimbra, Faculty of Economics, Av. Dias da Silva, 165, 3004-512 - Coimbra, Portugal; University of Minho, Economic Policies Research Unit (NIPE), Campus of Gualtar, 4710-057 - Braga, Portugal. Email: vcastro@fe.uc.pt.

$\S$ Corresponding author. LeBow College of Business, Drexel University, 3200 Market Street, Philadelphia, PA 19104, USA; IPAG Business School, 184, Boulevard Saint-Germain, 75006 Paris, France. Email: hammousm@drexel.edu.

ฯ University of Minho, Department of Economics and Economic Policies Research Unit (NIPE), Campus of Gualtar, 4710-057 - Braga, Portugal; London School of Economics and Political Science, LSE Alumni Association, Houghton Street, London WC2 2AE, United Kingdom. Emails: rjsousa@eeg.uminho.pt, rjsousa@alumni.lse.ac.uk. 


\section{Introduction}

Oil prices have a boom-bust cycle that may stretch between 10 to 15 years, but their short-run effects can also be global. ${ }^{1}$ Housing prices in different countries share a similar cycle pattern. For example, in countries like Spain, the United Kingdom or the United States, the housing market dynamics display the typical boom-bust cycle that follows a prolonged normal time period (Young, 2013; Agnello et al., 2015). Even the Great Recession emerged near the end of a large oil shock, which led to a downturn in housing prices and triggered the financial crisis of 2008-2009 (Hamilton, 2009). ${ }^{2}$ Thus, there is a potential link between the oil price and housing price cycles (Hamilton, 2011).

The existing literature embraces different channels through which commodity prices and housing prices may be associated. First, energy price increases have both direct and indirect impacts on disposable income and household spending (i.e., the income and demand effects), as they raise unemployment rates, shrink the purchasing power and squeeze profits in oil importing countries at the benefit of oil exporters. ${ }^{3}$ This has a detrimental effect on housing demand (Spencer et al., 2012). Kaufmann et al. (2011) also find a reasonable correlation between household energy expenditure and US mortgage delinquency rates.

Second, energy price surges have both direct and indirect effects on construction costs, whether in terms of producing and operating equipment and consuming raw materials, and hence affect the quantities and the prices of houses. Moreover, Quigley (1984) shows that increases in energy price can lead to a reasonable rise in the housing service costs. Similarly, as the housing sector represents a large fraction of overall energy consumption in OECD countries, rising energy costs can have a large impact on housing prices (Swan and Ugursal, 2009).

Third, energy price increases can affect the headline inflation rate and induce a tightening in monetary policy, which erodes liquidity and can in turn reduce housing demand (Edelstein and Kilian, 2009).

Fourth, since the financialisation of commodities is important, a sharp rise in energy prices can increase the attractiveness of commodities and generate large portfolio rebalancing effects away from stocks and houses and towards commodities through capital flows (Caballero et al., 2008; El-Gamal and Jaffe, 2010; Basu and Gavin, 2010).

Fifth, common factors (such as changes in the regulation and supervision of financial markets, global economic growth and variations in global liquidity) can influence the joint dynamics of commodity and housing prices where periods of expansion in global liquidity have typically coincided with substantial increases in commodity prices (Hammoudeh and Yuan, 2008; Batten et al., 2010; Belke et al., 2010; Ratti and Vespignani, 2013, 2015; Belke et al., 2014; Frankel, 2014).

\footnotetext{
${ }^{1}$ Innovations, commercial interests, geopolitics, and military conflicts have generally been the drivers of the boom-bust cycle of the oil industry (El-Ramly, 2015; Groneworld, 2015).

${ }^{2}$ Fluctuations in commodity prices may be predictors of future industrial production (Sadorsky, 1999; Park and Ratti, 2009; Narayan and Sharma, 2011) and other real economic activity (Hamilton, 1996, 2003, 2011). Earlier studies show that housing price downturns and oil price spikes tend to go hand in hand with the likelihood of economic recessions (Hamilton, 2003, 2005). Leamer (2007) argues that, despite representing a relatively small component of GDP, the housing sector plays a major role during recessions, contributing to their persistence and severity. Hamilton (2011) also argues that the relationship between housing price corrections and energy price volatility strengthened during the Great Recession.

${ }^{3}$ Leung et al. (2013) highlight that in an open economy commodity prices can affect the price of non-tradable goods (such as housing). Following Chen and Rogoff (2003), the authors highlight that commodity price fluctuations can be seen as "exogenous shocks", especially in countries where primary commodities represent a large fraction of total exports and thus have a major impact on the terms of trade. This is considered in the literature as a form of resource curse. Therefore, housing prices in some cities of those countries can be interpreted as "commodity house prices".
} 
Sixth, depreciating domestic currencies attract foreign buyers of domestic properties and can contribute to housing booms and busts.

Seventh, in the specific case of emerging market economies, Chiquier and Lea (2009) highlight the importance of the expansion of housing finance and underline its major drivers, including (i) lower inflation and mortgage interest rates; (ii) stronger housing demand related to demographic factors and urbanization; and (iii) financial liberalization. Additionally, the global commodity price boom of 2000-2008 and the rapid growth had induced large capital inflows (Higgins et al., 2006). ${ }^{4}$ This can lead to exceptionally large fluctuations in asset prices, including house prices.

In our paper, we investigate the potential spillovers from a series of oil-related variables to the duration of various phases of the housing market cycle for net oil-exporting and -importing countries. More specifically, we use quarterly data for a group of 20 industrialized countries and conduct a preliminary detection of upturns and downturns in real housing prices to identify periods of booms, busts and normal times in the housing market while taking into account their magnitude, persistence and severity. Then, we rely on both continuous-time and discrete-time Weibull models to assess the impact of the oil sector dynamics on the housing cycle.

Our results show that the duration of housing booms of both net oil importers and exporters falls when oil prices increase. Moreover, net oil importers seem to be less vulnerable to protracted housing busts than net oil exporters. ${ }^{5}$ Additionally, increases in the price of oil during normal times in the housing market cycle can well be described as an improvement in economic conditions.

The remainder of this paper is organized as follows. Section 2 presents the modeling approaches and Section 3 describes the data. Section 4 analyzes the empirical results. Finally, Section 5 concludes.

\section{Modelling Approaches}

\subsection{The continuous-time duration model}

The duration variable is defined as the number of periods - quarters in this study - over which a housing market boom, bust or normal cycle takes place. If $T$ is defined as the discrete random variable that measures the time span between the beginning of one of those events and the moment it ends, the series of data at our disposal $\left(t_{1}, t_{2}, \ldots, t_{n}\right)$ will represent the duration of those events. The probability distribution of the duration variable $T$ can be specified by the cumulative distribution function (CDF) $F(t)=\operatorname{Pr}(T<t)$. This function measures the probability of the random variable $T$ being smaller than a certain value $t$. A particularly useful function for the duration analysis is the hazard function

$$
h(t)=f(t) / S(t),
$$

\footnotetext{
${ }^{4}$ Cesa-Bianchi et al. (2015) show that, compared to advanced countries, housing prices have larger growth rates, higher volatility, and lower degree of synchronization and persistence in emerging market economies. Their correlation with capital flows is also stronger and they are more sensitive to global liquidity shocks. In addition, house prices are strongly procyclical in emerging markets (Igan and Loungani, 2012). Ciarlone (2012) find that house prices in emerging economies are not largely disconnected from fundamentals, but the adjustment to the latter is slow and overly optimistic expectations were more prominent before the onset of the global financial crisis.

${ }^{5}$ In this context, our work is highly indebted to Breitenfellner et al. (2015), who find that a rise in energy inflation strongly increases the probability of a correction in housing prices. Therefore, the pass-through of oil prices to financial markets is important, and energy price inflation can be thought as a macro-financial risk indicator.
} 
where $f(t)$ is the respective density function, while $S(t)=\operatorname{Pr}(T \geq t)=1-F(t)$ is the survival function which measures the probability of an event surviving for $t$ or more time. The hazard function reflects the rate at which housing booms, busts or normal times will end at $t$, given that they lasted until that moment. In other words, this function captures the probability of exiting from a state in moment $t$ conditional on the length of time in that state. From the hazard function, we can derive the integrated hazard function, $H(t)=\int_{0}^{t} h(u) d u$, and the corresponding survival function, $S(t)=\exp [-H(t)]$.

The hazard function allows for a characterization of the dependence duration path. If $d h(t) / d t>0$, there is a positive duration dependence, that is, the probability of a housing boom, bust or normal time ending at $t$, given that it has reached $t$, increases with its age. Thus, the longer the respective event is, the higher the conditional probability of it ending will be.

We use a proportional hazards model to parameterize the hazard function: ${ }^{6}$

$$
h(t, \mathbf{x})=h_{0}(t) \exp \left(\boldsymbol{\beta}^{\prime} \mathbf{x}\right)
$$

where $h_{0}(t)$ is the baseline hazard function that captures the duration dependence of the data, $\boldsymbol{\beta}$ is a $(K \times 1)$ vector of parameters to be estimated and $\mathbf{x}$ is a vector of covariates that do not vary over the duration of the event. This model is suitable for the analysis of the duration of the various phases of the housing market cycle, as we can impose a specific parametric form to the function $h_{0}(t)$ to estimate the magnitude of the duration dependence. In fact, the Weibull distribution fits perfectly this goal. Hence, the respective (baseline) hazard function is given by:

$$
h_{0}(t)=\gamma p t^{p-1}
$$

with $\gamma>0$ and $p>0$. In this hazard function, $\gamma$ is a constant and $p$ parameterizes the duration dependence. This means that if $p>1$, the conditional probability of a turning point occurring will increase as the phase gets older, i.e. there will be positive duration dependence. However, a negative duration dependence is observed when $p<1$, but if $p=1$, there will be no duration dependence. Therefore, as intended, by estimating $p$, we can test for duration dependence in housing booms, busts and normal times.

Including the Weibull specification for the baseline hazard function in the proportional hazard function given above by equation (2), we have:

$$
h(t, \mathbf{x})=\gamma p t^{p-1} \exp \left(\boldsymbol{\beta}^{\prime} \mathbf{x}\right) .
$$

Hence, the corresponding survival function can be written as follows:

$$
S(t, \mathbf{x})=\exp [-H(t, \mathbf{x})]=\exp \left[-\gamma t^{p} \exp \left(\boldsymbol{\beta}^{\prime} \mathbf{x}\right)\right]
$$

This model can be estimated by Maximum Likelihood. The likelihood function for a sample of $i=1, \ldots, n$ spells is given by

$$
L(\cdot)=\prod_{i=1}^{n} f\left(t_{i}, \mathbf{x}_{i}\right)=\prod_{i=1}^{n} h\left(t_{i}, \mathbf{x}_{i}\right)^{c_{i}} S\left(t_{i}, \mathbf{x}_{i}\right),
$$

\footnotetext{
${ }^{6}$ This means that the ratio of the hazard rates for any pair of observations is constant over time.
} 
where $c_{i}$ indicates when observations are censored. If the sample period under analysis ends before the turning point has been observed, the observations will be censored $\left(c_{i}=0\right)$; if the turning points are observed in the sample period, the observations will not censored $\left(c_{i}=1\right)$.

Following Allison (1982), the corresponding log-likelihood function with the respective Weibull hazard and survival functions can be written as follows:

$$
\ln L(\cdot)=\sum_{i=1}^{n}\left[c_{i}\left(\ln \gamma+\ln p+(p-1) \ln t_{i}+\boldsymbol{\beta}^{\prime} \mathbf{x}_{i}\right)-\gamma t_{i}^{p} \exp \left(\boldsymbol{\beta}^{\prime} \mathbf{x}_{i}\right)\right]
$$

Although the life of a housing boom, a bust or a normal time is a continuous-time process, the available data is inherently discrete, which leads us to consider, in addition, a discrete-time duration analysis.

\subsection{The discrete-time duration model}

When the discrete units are very small, one can treat time as if it is continuous (Allison, 1982). However, when the time units are very large, a discrete-time duration analysis may be more adequate. This can be particularly relevant in the case of housing market cycles, where the available data is grouped into large (quarterly) discrete-time intervals. Therefore, we rely not only on continuous-time Weibull models to analyse the presence of duration dependence in the housing market cycle - as Agnello et al. (2015) do -, but also on discrete-time Weibull models, which have the advantage of easing the inclusion of time-varying covariates (see Agnello et al. (forthcoming)) ${ }^{7}$

To implement discrete-time methods, we start with a continuous-time model (namely, the proportional hazards model) and, then, derive the appropriate estimator for the data grouped into intervals. A discretetime (grouped data) version of the proportional hazards model was developed by Prentice and Gloeckler (1978) and Allison (1982), from where we can define the discrete-time hazard rate as follows:

$$
P_{i t}=\operatorname{Pr}\left[T_{i}=t \mid T_{i}>t, \mathbf{x}_{i t}\right]
$$

where $T_{i}$ is the discrete random variable representing the uncensored time at which the event (boom, bust or normal time) ends and $x_{i t}$ is a vector of time-varying explanatory variables. It is also assumed that time can only take integer values (i.e. $t=1,2,3, \ldots$ ) and that we observe $n$ independent spells (i.e. housing booms, busts or normal times; $i=1,2, \ldots, n)$ starting at $t=1$. The observation continues until time $t_{i}$, at which either an event occurs or the observation is censored, i.e. the event is observed at $t_{i}$, but not at $t_{i+1}$. Therefore, $P_{i t}$ measures the conditional probability of event $i$ ending at time $t$, given that it has not ended yet.

Following Prentice and Gloeckler (1978), the corresponding discrete-time proportional hazard function can be written as:

$$
P_{i t}=1-\exp \left[-h_{t} \exp \left(\boldsymbol{\beta}^{\prime} \mathbf{x}_{i t}\right)\right]=1-\exp \left[-\exp \left(\theta_{t}+\boldsymbol{\beta}^{\prime} \mathbf{x}_{i t}\right)\right] .
$$

\footnotetext{
${ }^{7}$ Compared to the work of Agnello and Schuknecht (2011), who focus on the particular features of each phase of the housing market cycle, our framework also takes into account the relevance of own age (history) in explaining them. Thus, it helps to explain the transition across the various phases of the housing cycle and its likely driving forces.
} 
This function is equivalent to the complementary $\log -\log$ (or cloglog) function:

$$
\ln \left[-\ln \left(1-P_{i t}\right)\right]=\theta_{t}+\boldsymbol{\beta}^{\prime} \mathbf{x}_{i t},
$$

where $\theta_{t}\left(=\ln h_{t}\right)$ denotes the logarithm of an unspecified baseline hazard function of time, while $\beta$ is the vector of parameters associated to the time-varying explanatory variables, $x_{i t}$, as in equation (2).

To proceed with the estimation, we need to choose a functional form for $\theta_{t}$. As is common in the literature, we opt for a discrete-time model that is analogue to the Weibull model:

$$
\theta_{t}=\ln h_{t}=\alpha+(p-1) \ln t
$$

Alternatively, $\theta_{t}$ can be specified as: $(i)$ a polynomial-in-time $\left(\theta_{t}=\alpha_{0}+\alpha_{1} t+\alpha_{2} t^{2}+\alpha_{3} t^{3}+\ldots\right)$, where we may have linear, quadratic, cubic or other polynomials for the hazard function; (ii) piecewise-dummies $\left(\theta_{t}=\alpha_{0}+\alpha_{1} d_{1}+\alpha_{2} d_{2}+\alpha_{3} d_{3}+\ldots\right)$ - i.e., one dummy for each particular sub-period of time - where the hazard rate is assumed to be the same within each time-group, but different between those groups; or (iii) a fully non-parametric specification with one dummy for each value of $t$ for which an event is reported (time-dummies). Given their flexibility, some of these alternatives will be evaluated in this study.

The discrete-time $\log$-likelihood function for a sample of $i=1, \ldots, n$ spells is given by:

$$
\ln L(\cdot)=\sum_{i=1}^{n} \sum_{j=1}^{t_{i}} y_{i t} \ln \left(\frac{P_{i j}}{1-P_{i j}}\right)+\sum_{i=1}^{n} \sum_{j=1}^{t_{i}} \ln \left(1-P_{i j}\right),
$$

where the dummy variable $y_{i t}$ is equal to 1 if the housing boom, bust or normal time $i$ ends at time $t$, and

0 otherwise. After replacing equation (10) into (12) and using the adequate specification for the baseline hazard function, the model can be estimated via a maximum likelihood estimator (MLE).

\subsection{Variable selection}

The selection of covariates $\mathbf{x}_{i t} \in \mathbf{X}$ entering the discrete-time version of the duration model is driven by theoretical arguments and the existing empirical evidence presented in Section 1.

In order to investigate the potential spillovers from fluctuations in the oil price to the duration of housing booms, busts and normal times (i.e., the "oil price" transmission channel), we consider the following set of oil-related indicators $\left(\mathbf{X}_{\text {oil }}\right)$ : 1) net oil exports as a percentage of GDP (NetExp); 2) a dummy variable that takes the value of one when the country is a net oil importer in 2012 (fixed definition based on the last year of the sample for which data are available), and zero otherwise (OilImpF);3) a dummy variable that takes the value of one when the country is a net oil importer (contemporaneous definition), and zero otherwise $(\operatorname{OilImpC}) ; 4)$ the oil price for each individual country $(\mathrm{OilPr})$; and 5) the world oil price (WOilPr).

We remark that the distinction between net oil exporters and net oil importers is particularly useful in the assessment of the macroeconomic impact of oil prices on the housing cycle. For instance, if oil price falls, net oil importers are expected to benefit from real income gains as a result of an improvement in their terms 
of trade. The opposite occurs in countries where the oil sector is large or even dominant and other activities depend on oil revenues, including public and private spending (i.e. for net oil exporters).

Each variable of the vector $\mathbf{X}_{\text {oil }}$ is added (one at time) to the set of macroeconomic variables $\left(\mathbf{X}_{\text {macro }}\right)$, which are considered as the main drivers of the housing market cycle. In this context, studies by Agnello and Schuknecht (2011) and Taylor (2007) show that interest rates are expected to have an impact on the dynamics of housing prices (both directly or indirectly (via their effect on money and credit availability)), as they influence the probability of housing price booms and busts. In line with this view, we have included the lending rate $(\operatorname{LendIR})$ among the set of explanatory variables. Following Agnello et al. (forthcoming), we have also considered the role of the "credit channel" as represented by growth rate of domestic credit to the private sector $(C r e d)$ and the "income channel" as defined by the growth rate of real GDP $(G D P)$. Overall, we expect that better economic conditions and easier access to credit (due to lower interest rates and/or wider credit availability) contribute to reduce (increase) the probability of housing booms (busts) ending.

Finally, a dummy variable (European) is also included among the set of regressors to test the possible existence of significant differences in the length of housing booms/busts in European countries vis-à-vis non-European countries.

Summing up, it follows that the hazard function (8) can be conveniently re-written as:

$$
P_{i t}=\operatorname{Pr}\left[T_{i}=t \mid T_{i}>t,\left\{\mathbf{X}_{o i l}, \mathbf{X}_{\text {macro }}\right\}\right]
$$

\section{Data}

As indicated, our analysis covers a sample of 20 industrialized countries over the period 1970Q1-2012Q2. ${ }^{8}$ The quarterly data on the housing prices index $(H P)$ are provided by the Organisation for Economic CoOperation and Development (OECD). The time series of the real GDP growth rate $(G D P)$, the lending interest rate $($ LendIR) and the growth rate of domestic credit to the private sector $(C r e d)$ are obtained from the International Financial Statistics of the International Monetary Fund (IMF). The data for net oil exports come from the IMF, the individual-country oil price data is gathered from the OECD, and the world oil price is provided by the Dow Jones \& Company. The data used in duration analysis are organized in spells, which, in our study, represent the duration of a boom, a bust or a normal period, denoted by Dur. ${ }^{9}$

The episodes of booms and busts in housing markets are identified using a simple statistical approach as in Agnello et al. (2015, forthcoming) and Burnside et al. (2016). Given the quarterly frequency of our data, we start by smoothing the logarithm of real housing price series, $Y_{t}$, to avoid capturing undesirable high-frequency movements. Thus, we compute their centered-moving average, that is, $\bar{Y}_{t}=\sum_{j=-n}^{n} Y_{t+j} / 2 n$. Then, we define an 'upturn' as an interval of time during which $\Delta \bar{Y}_{t}>0$ for all $t$, while we denote a 'downturn' as an interval of time in which $\Delta \bar{Y}_{t}<0$. A peak or trough is the last period within an upturn and a downturn, respectively. The price change in a run-up (downturn) is required to exceed (fall below) a

\footnotetext{
${ }^{8}$ The countries included in our sample are: Australia, Belgium, Canada, Denmark, Finland, France, Germany, Greece, Ireland, Italy, Japan, Korea, Netherlands, New Zealand, Norway, Spain, Sweden, Switzerland, the United Kingdom, and the United States.

${ }^{9}$ Dur corresponds to $t_{i}$ in the model described in the previous Section.
} 
minimum (maximum) bound before it can be labelled as a boom (bust). It follows that a housing boom is defined as an upturn such that $\bar{Y}_{T}-\bar{Y}_{T-L}>z$ and, analogously, a housing bust is a downturn for which $\bar{Y}_{T}-\bar{Y}_{T-L}<-z$, where $T$ indicates the peak of the boom or the trough of the bust and $L$ is the duration of the upturn or the downturn. The identification of booms and busts is based on the assumption that $n=5$ and $z=0.15 .{ }^{10}$ To the extent that housing booms and housing busts reflect house price misalignments, then we can interpret the normal times in housing markets as periods during which house prices are in line with their equilibrium values.

\section{Empirical Results}

We begin the empirical analysis by presenting in Figure 1 the scatter diagrams of the (non-negative) duration of boom, bust and normal periods in the housing market and the oil price for each individual country $(\mathrm{OilPr})$. As can be seen, they suggest that the length of housing booms is negatively associated with oil prices. In contrast, the duration of housing busts seems to be negatively linked with the dynamics of oil prices. Finally, for normal time spells, the relationship between duration and oil prices does not display a clear pattern.

\section{[INSERT FIGURE 1 AROUND HERE]}

Figure 2 plots the hazard rates and the survival functions for the duration of housing booms, busts and normal times. The hazard rates show that, for all phases of the housing market cycle, the conditional probability of the respective spell ending at time $t$, given that it has not ended yet, tends to increase over time. Therefore, as time goes by and each phase becomes older, the likelihood that it will end rises. Consequently, the survival functions steadily fall for housing booms, housing busts and normal times. However, this piece of evidence does not allow us to assess whether such patterns are statistically significant and, most importantly, if they can be explained by oil price developments.

\section{[INSERT FIGURE 2 AROUND HERE]}

To address these issues, a deeper statistical examination with parametric continuous-time and discretetime duration models is provided in Tables 1 to 9. While testing for duration dependence, we also assess whether, as argued by Zellner (1990) and Sichel (1991) for the business cycles, the duration of the previous housing market's phase affects the length of the current one. Hence, we include the dummy variable, DurPrev, among the set of time-invariant regressors (of the continuous-time duration models). We also control for the typology of the previous phase by adding the dummy variable Prev. This takes the value of one if the preceding phase of a boom was a bust (i.e. a "bust-boom" cycle), and zero otherwise; analogougly, it takes the value of one if the preceding phase of a bust was a boom (i.e. a "boom-bust" cycle), and zero otherwise. Finally, during normal times, it takes the value of one if the preceding phase was a boom (i.e. a "cyclical slowdown"), and zero if it was a bust (i.e. a "cyclical recovery").

\footnotetext{
${ }^{10}$ We note note that the empirical evidence is robust to small changes in these parameters.
} 


\subsection{From the oil sector to housing booms?}

Tables 1-3 present the results for housing booms. In Table 1, we report the findings associated with the continuous-time Weibull model. Only the duration dependence parameter $(p)$ and a set of relevant timeinvariant variables are considered in this framework. The latter includes: $i$ ) a dummy variable Event, which allows us to analyze whether the durations of booms, busts and normal times becomes gradually longer or shorter over time. This variable reports the order or the observation number of each event over time and for every single country. It is equal to 1 for the first event, 2 for the second one, and so on. If the coefficient associated with this variable is significantly smaller (larger) than zero, phase durations get longer (shorter) over time; $i i)$ the type of the previous phase (Prev) and the duration of the previous phase (DurPrev) as discussed in the previous section 4; iii) a dummy for European countries (European), which takes the value of one for European countries, and zero otherwise and allows us to test whether there is a significant difference in the average duration of housing price phases between European and non-European countries; $i v$ ) a set of dummy variables which control for whether a country is a net oil importer or not (i.e. OilImpF and $O$ OilImpC).

In what concerns the characteristics of housing boom episodes, the results suggest the existence of positive duration dependence, as $p$ is statistically greater than 1. Moreover, the second derivative of the baseline hazard function $\left(h_{0}(t)=\gamma p t^{p-1}\right)$ indicates the presence of constant positive duration dependence (i.e. $p$ is statistically equal to 2), which means that the probability of a housing boom ending at time $t$, given that it lasted until that period, increases over time but at a constant rate (Castro, 2010). Moreover, the empirical findings show that booms have become longer over time, as the coefficient of Event is negative, implying that the likelihood of a boom ending fell over time. There is also some weak evidence that the longer the previous phase is (no matter what, as the coefficient of Prev is not statistically significant), the smaller the likelihood of a housing boom ending tends to be.

Regarding the influence of the other time-invariant controls, we find that no significant differences in the duration of housing booms between European and non-European countries (i.e. European is not statistically significant). Most importantly for the scope of this paper, we do not uncover a different duration of this phase of the housing market cycle between net oil importers and exporters, as the variables OilImpF and OilImpC are not significant. This implies that housing booms tend to be similar for net oil importers and exporters. However, this is only a preliminary result. Indeed, some further analysis requires one to account for other oil-related variables that are time-varying (e.g. oil prices).

\section{[INSERT TABLE 1 AROUND HERE]}

This is done in Table 2, which reports the results associated with the estimation of the discrete-time Cloglog model. To begin with, we consider the following specification for the logarithm of the baseline hazard function in the discrete-time cloglog model: $\theta_{t}=\alpha+(p-1) \ln t$, where $t$ measures the duration of a housing boom, i.e., $t=$ Dur. The results corroborate the finding of the continuous-time model regarding the duration dependence: the likelihood of a housing boom ending increases over time at a constant (or even increasing) rate. 
Regarding the relevance of time-invariant controls, we get some evidence pointing to a longer duration of housing booms in the group of European countries. As in the case of the continuous-time duration model, no significant difference is found between net oil importers and net oil exporters. Similarly, the coefficient associated with the variable that captures the country's oil dependence (i.e. net oil exports (as percentage of GDP), (NetExp)) is not statistically significant.

However, looking at the time-varying oil-related variables, some interesting conclusions emerge. In particular, we emphasize that the price of oil significantly affects the duration of housing booms. That is, the higher the oil price in a specific country $(O i l P r)$ is, the higher the likelihood of a housing boom ending is. More specifically, when the oil price increases by one US dollar per barrel, the hazard rate (or the odds) of a housing boom ending rises by a factor of, approximately, $e^{0.042}=1.043$, that is, by close to $4.3 \%$, ceteris paribus. The same applies when we consider the world oil price (WOilPr): the coefficient associated with this variable is positive, which implies that a rise in the world price of oil increases the probability of ending a housing boom. ${ }^{11}$ Thus, the duration of housing booms is significantly shortened by increases in the world price because they raise construction costs, reduce disposable income and hike inflation expectations and the probability of teetering into recession.

Putting these results into perspective, they suggest that increases in oil prices are counter-cyclical and can act as an automatic stabilizer of the economy vis-à-vis periods of large and prolonged appreciation in real housing prices. This is true for the oil-importing countries. From a more managerial and practitioner point of view, investors should re-balance their portfolios by adopting short positions in real estate when faced with oil price hikes during housing booms. Therefore, the liquidity of the real estate market in the oil-importing countries should matter for investors. Concerning the net-oil exporting countries, strong increases in oil prices raise all the boats including houses. Thus, oil prices are cyclical for these countries. All in all, both oil-exporting and importing countries have oil risk exposures but at different sides of the business cycle.

Turning to the role played by the other macroeconomic factors $\left(X_{\text {macro }}\right)$, we show that: $(i)$ when the growth rate of real GDP (GDP) increases, the likelihood of a housing boom ending falls even though the effect is not significant; ( $i i)$ housing booms tend to be significantly shorter when the interest rate (LendIR) increases. In particular, a one percentage point rise in the interest rate boosts the hazard rate (or the odds) of a housing boom ending by a factor of, approximately, $e^{0.4}=1.492$, i.e., by about $50 \%$, ceteris paribus ${ }^{12}$ (iii) the credit growth rate $(\mathrm{Cr} e d)$ does not influence the duration of housing booms. Consequently, measures aimed at controlling credit supply are likely to be ineffective in influencing housing prices.

\section{[INSERT TABLE 2 AROUND HERE]}

Finally, Table 3 summarizes the findings associated with the estimation of Cloglog regressions that are performed using natural cubic splines of the hazard functions. Given that the Weibull model is restrictive regarding the shape of the hazard function since it assumes that this function can only rise or decline in

\footnotetext{
${ }^{11}$ This result is possibly more relevant for the oil-importing countries than for the oil-exporting countries where the housing sector usually booms in an environment of rising oil prices. However, the lack of a reasonably large number of usable data points invalidates any statistical inference based on sub-sample analysis.

${ }^{12}$ Note that the estimated coefficients on this variable presented in Table 2 vary between 0.360 and 0.426 , implying a change in the hazard rate of between $43.3 \%$ and $53.1 \%$.
} 
a monotonic way, we consider other more flexible specifications. More specifically, we use "natural cubic splines" (i.e. cubic polynomials of $t$ (or Dur)) to smooth the coefficients of the hazard function based on them. The results with three cubic splines (i.e., Spline1, Spline 2 and Spline3, each of them referring to the linear, quadratic and cubic term, respectively) show that the coefficients of the covariates remain significant and have the expected signs. Moreover, the coefficients of the three cubic splines are also highly significant. ${ }^{13}$ Thus, the likelihood of a housing boom ending appears to behave in a nonlinear way and the Cloglog specification represents the best framework to study the duration of housing booms and the one that provides the most accurate characterization of the likelihood that they end after a certain duration.

In line with the previous duration models, we find that: $(i)$ an increase in oil prices raises the probability of a housing boom ending; (ii) higher lending rates significantly reduce the length of housing booms; and (iii) neither the growth rate of real GDP, nor the growth rate of domestic credit to the private sector exert a significant impact on the duration of housing booms.

\section{[INSERT TABLE 3 AROUND HERE]}

\subsection{From the oil sector to housing busts?}

The empirical evidence regarding housing busts is reported in Tables 4-6. Once again, we start by considering the basic continuous-time Weibull model (Table 4). The results point to the presence of constant positive duration dependence, as $p$ is statistically greater than 1 and statistically equal to 2 , which means that the probability of a housing bust ending at time $t$, given that it lasted until that period, increases over time at a constant rate. There is some evidence that the longer the previous phase is (no matter what, as the coefficient associated with Prev is not statistically significant), the smaller the likelihood of a housing bust ending tends to be.

Regarding the influence of time-invariant controls, our results do no point to significant differences in the duration of housing busts between European and non-European countries. As for DurPrev, despite its negative coefficient suggesting that longer booms or normal time periods are followed by longer housing busts, it is not statistically significant. Interestingly, we find that the fact that a country is a net oil importer $($ OilImpF and OilImpC) is associated with an increase of the duration of housing busts. More specifically, this phase of the housing market cycle tends to be longer in net oil importing countries. In fact, the coefficients associated with these dummy variables are negative and statistically significant. Therefore, net oil importers typically face longer housing bust spells than net oil exporting countries. In economic terms, the coefficients associated with OilImpF and OilImpC range between -1.625 and -1.443 , which implies that being an oil importer reduces the likelihood of the end of a housing bust by between $76.4 \%$ and $80.3 \%$.

The net oil-importing countries tend to have a larger and more diversified economy. They also have higher deficit-to-GDP and debt-to-GDP ratios which impair the operation of the fiscal policy and slow down adjustments during slump periods. On the other hand, the net oil-exporting countries are usually less diversified and commodity-based but they have less debt and large foreign reserves and sovereign wealth

\footnotetext{
${ }^{13}$ The three spline-basis variables correspond to "knots" at terms 1,30,45 and 68, respectively. This set of knots is chosen because it produces statistically significant variables and the lowest $p$-values in terms of the rejection of the null hypothesis in likelihood ratio tests applied to the three cubic splines. A 3 - knot solution is also tried (two cubic splines), but the $A I C$, $S B I C$ and $L R I$ are lower. Hence, the model with three cubic splines is the preferred one. These results are available upon request.
} 
funds which they can use to re-jump their economies quicker than net oil-importing countries. In sum, during slump periods, the exposure of the net oil-exporting countries to oil price risk is more manageable than for the net oil-importing countries.

\section{[INSERT TABLE 4 AROUND HERE]}

When time-varying covariates are included in the discrete-time Cloglog model (Table 5), we observe that the (constant) positive duration dependence still characterizes housing busts.

Moreover, the results from this discrete-time duration model are in line with its continuous-time counterpart regarding the European dummy variable and, most importantly, they confirm that net oil importers face longer housing bust spells than net oil exporters. Other oil-related variables, such as net oil exports (as percentage of GDP) (NetExp) and oil prices (OilPr and WOilPr) do not seem to significantly affect the duration of housing busts.

In line with our expectations, the results indicate that housing busts are mainly influenced by the economic environment or economic activity. That is, when the growth rate of real GDP $(G D P)$ increases, the likelihood of a housing bust ending rises. A quantitative assessment reveals that the point coefficient estimates associated with $G D P$ lie between 0.305 and 0.360 , thereby implying that the duration of housing busts is reduced by between $33.2 \%$ and $44.6 \%$ when the growth rate of real GDP raises by one percentage point. The coefficient of Cred is not significant, but LendIR has a positive impact on the likelihood of a housing bust ending.

In light of the relevance of GDP growth as a driver of the duration of housing slumps, this finding suggests that authorities in oil-importing countries may need to put in place more expansionary policies (such as, large (fiscal) stimuli packages) to be able to deliver an effective recovery of the housing sector compared to oil-exporting economies (as in the case of many emerging markets).

\section{[INSERT TABLE 5 AROUND HERE]}

Finally, Table 6 provides a summary of the estimation of Cloglog regressions that are performed using natural cubic splines of the hazard functions. Again, we find that the three cubic splines (Spline1, Spline2 and Spline3) are statistically significant, thereby suggesting that the likelihood of a housing bust ending displays some nonlinearity. In addition, we confirm that: $(i)$ the longer exposure of net oil importers to protracted housing busts vis-à-vis other countries; and (ii) the crucial role of improvements in real economic activity as a way to shorten housing busts;

\section{[INSERT TABLE 6 AROUND HERE]}

\subsection{What do oil prices mean for normal times in the housing cycle?}

We now turn to the duration analysis of normal times in the housing market cycle (Tables 7-9). In Table 7, it can be seen that the likelihood of normal times ending depends on the length of this phase of the 
cycle. Moreover, the coefficient $p$ is statistically greater 1 , but statistically lower than 2 , which means that the probability of normal times ending at time $t$, given that they have lasted until that period, increases over time at a decreasing rate.

The results also indicate that the duration of normal times: $(i)$ has not increased over time (the coefficient associated with Event is not significant); and ( $i i)$ is independent of whether the previous event was a boom or a bust (as reflected in the lack of statistical significance of Prev). Yet, there is some weak evidence suggesting that the longer those spells are, the longer normal times will be (in accordance with the negative coefficient associated with DurPrev). Moreover, normal time spells in the housing market are, on average shorter in the European than in the non-European countries. This indicates that the European countries may move more quickly from a normal period to a housing boom than the non-European countries.

The empirical evidence also shows that the duration of normal times in the housing market is not significantly different between the net oil importers and the net oil exporters.

\section{[INSERT TABLE 7 AROUND HERE]}

This is confirmed by the discrete-time model that is analogue to the continuous-time Weibull model (Table 8). Similarly, net oil exports (as percentage of GDP) (NetExp) - i.e., a measure of the oil dependence of a country - does not significantly impact the duration of normal time spells. However, the price of oil has a significantly negative effect on the likelihood of normal times' ending. Thus, in general, a rise in the price of oil tends to be associated with longer normal time spells before they, eventually, turn into housing booms. This result can be explained by the fact that increases in oil prices generally reflect an improvement of real economic activity, therefore, being associated with stronger fundamentals. Consequently, oil price fluctuations can be used as informative signals for investors when considering their asset portfolio allocations. More specifically, oil price increases (decreases) should be exploited by means of larger (smaller) exposure to equities to the extent that they reflect expectations of stronger (weaker) economic fundamentals.

This interpretation is corroborated by the empirical evidence concerning the set of macroeconomic determinants. In fact, we find that normal times in the housing market are mainly affected by the economic environment or economic activity, that is, these spells are shorter when GDP growth accelerates. Put it differently, when economic conditions improve, the housing market might enter a boom state and, as long as the GDP growth keeps rising, the housing sector dynamics will remain in this phase over longer time spells. In quantitative terms, a one percentage point rise in the growth rate of real GDP leads to an increase in the likelihood of the end of a normal time spell by around $36.2 \%-46.2 \%$.

The empirical findings also reveal that a higher lending interest rate impinges negatively on the duration of normal times by shortening it and, possibly, bringing the market to a housing bust. Thus, a one percentage point increase in the lending interest rate raises the probability of normal times ending by about $10 \%$.

\section{[INSERT TABLE 8 AROUND HERE]}

Finally, in Table 9 we can see that the Cloglog regressions that are performed using natural cubic splines of the hazard functions for normal times confirm the previous results. Thus: $(i)$ increases in oil prices are 
associated with a longer duration of normal times in the housing market, as they typically reflect increases in the demand for oil; (ii) an improvement in real economic activity can shorten normal time spells (by promoting the transition to a housing boom); (iii) a tightening of money market conditions reduces the length of normal times (by increasing the likelihood of a housing bust); and (iv) normal time spells are on average shorter in the European countries than in the non-European countries. All three cubic splines of the hazard function are also found to be statistically significant, which gives rise to the importance of nonlinearity in the likelihood of normal times ending.

\section{[ INSERT TABLE 9 HERE. ]}

\section{Conclusions and Policy Implications}

Using quarterly data for 20 European and non-European countries, net oil exporting and importing industrialized countries, we assess the spillovers from the energy price fluctuations to the various phases of the housing market cycle (i.e., housing booms, housing busts and normal times), using various continuousand discrete-time duration models. We find that housing booms tend to be shorter for both oil importers and exporters when oil prices increase, reflecting probably a demand or a supply oil shock. With regard to the housing busts, the empirical evidence corroborates the idea that the net oil exporters appear to be more immune to prolonged housing busts than the net oil importers, possibly due to greater foreign reserves and more active fiscal policy. In what concerns normal times in the housing market, we show that oil price increases typically reflect an improvement in economic conditions. As a result, a rise in oil prices tends to shorten normal time spells, possibly, by promoting the entry to a housing boom phase. Additionally, we do not uncover a statistically significant difference in the average duration of housing booms and normal times in the housing market between the net oil importers and the net oil exporters. Similarly, the degree of exposure to commodity price fluctuations - which can be captured by net oil exports (as a percentage of GDP) - does not seem to affect the housing market cycle in a significant manner.

Turning to other major determinants of the housing market cycle, we confirm that economic growth reduces the length of housing busts, while lending rates hikes are associated with shorter housing booms.(see, for instance, Agnello et al. (forthcoming)). Hence, by helping to stimulate household income, cyclical policies (for instance, monetary policy expansions or fiscal policies specifically targeting the housing market like reductions of capital gains taxes on houses, taxes on home purchases, housing gains or the imputed rental value of the house and more tax deductibility of interest payments (Afonso and Sousa, 2011; Agnello et al., 2012)) can promote the recovery of the housing sector or dampen its imbalances.

All in all, our study suggests that measures, such as a better risk management via hedging against undesirable fluctuations in the price of oil, help to prolong the duration of normal time spells in the housing markets and may contribute to a sounder and more sustainable growth path. Similarly, by reducing a country's oil dependence, (public) investments in renewable energies can be a particularly effective strategy in oil importers as they will shorten the length of housing busts, thus avoiding the financial instability associated with boom-bust cycles. 
Due to the importance that money market conditions have on the duration of housing booms, our paper also highlights the influential role of monetary policy, specifically by illustrating the impact of lending rates on this phase of the housing market cycle. Hammoudeh et al. (2015) show that monetary contractions can lead to a persistent reduction in the prices of energy. This last result has an important implication for the current paper: by generating a prolonged fall in oil prices, monetary policy can also be crucial at preventing housing booms in a quasi-permanent manner, thus emerging as a counter-force to the important effects of the oil factor on the housing market cycle.

Finally, in a related work, Jawadi et al. (2016) highlight that policy coordination between central banks and government (in particular, in emerging markets) can be especially effective in terms of boosting recoveries from economic downturns. In light of the role played by economic growth at reducing the length of housing busts, such coordination between monetary and fiscal policies can prove particularly powerful at eliminating periods of protracted housing slumps, thus, maximizing the benefits of stabilization policies.

Apart from providing valuable information about the impact of oil price fluctuations on the length of boom-bust housing cycles, the current article also opens new research avenues for further work. For instance, Caporale and Sousa (2016) uncover heterogeneity in the treatment of financial and housing assets as complements or substitutes by investors in emerging markets. They show that this feature is explained by differences in the degree of equity market development and the level of income. Sousa et al. (2016) also find that, despite the reasonably good performance of the output gap to GDP ratio as a predictor, many domestic macroeconomic variables (such as inflation and interest rates) and macro-finance variables (such as the consumption-wealth ratio), as well as their international counterparts, are poor predictors of future equity returns in emerging markets. Thus, a promising direction that should be explored includes the assessment of the role played by such factors at explaining housing market cycles in emerging market economies. We leave this for future research.

\section{References}

[1] Afonso, A., Sousa, R.M., 2011. What are the effects of fiscal policy on asset markets? Economic Modelling, 28(4), 1871-1890.

[2] Agnello, L., Castro, V., Sousa, R.M., 2012. How does fiscal policy react to wealth composition and asset prices? Journal of Macroeconomics, 34(3), 874-890.

[3] Agnello, L., Castro, V., Sousa, R.M., 2015. Booms, busts and normal times in the housing market. Journal of Business and Economic Statistics, 33(1), 25-45.

[4] Agnello, L., Castro, V., Sousa, R.M., forthcoming. Economic activity, credit market conditions and the housing market. Macroeconomic Dynamics.

[5] Agnello, L., Schuknecht, L., 2011. Booms and busts in housing markets: Determinants and implications. Journal of Housing Economics, 20(3), 171-190. 
[6] Allison, P., 1982. Discrete-time methods for the analysis of event histories. Sociological Methodology, 13, 61-98.

[7] Basu, P., Gavin,W.T., 2010.What explains the growth in commodity derivatives? Federal Reserve Bank of St Louis Review, 93(1), 37-48.

[8] Batten, J.A., Ciner, C., Lucey, B.M., 2010. The macroeconomic determinants of volatility in precious metals markets. Resources Policy, 35, 65-71.

[9] Belke, A.H., Bordon, I.G., Hendricks, T.W., 2014. Monetary policy, global liquidity and commodity price dynamics. North American Journal of Economics and Finance, 28, 1-16.

[10] Belke, A., Orth, W., Setzer, R., 2010. Liquidity and the dynamic pattern of asset price adjustment: A global view. Journal of Banking and Finance, 34, 1933-1945.

[11] Breitenfellner, A., Crespo Cuaresma, J., Mayer, P., 2015. Energy inflation and house price corrections. Energy Economics, 48, 109-116.

[12] Caballero, R., Farhi, E., Gourinchas, P., 2008. Financial crash, commodity prices and global imbalances. Brookings Papers on Economic Activity, 2008 (Fall), 1-55

[13] Caporale, G.M., Sousa, R.M., 2016. Consumption, wealth, stock and housing returns: Evidence from emerging markets. Research in International Business and Finance, 36, 562-578.

[14] Castro, V., 2010 The duration of economic expansions and recessions: More than duration dependence. Journal of Macroeconomics, 32, 347-365.

[15] Cesa-Bianchi, A., Cespedes, L.F., Rebucci, A., 2015. Global liquidity, house prices and the macroeconomy: evidence from advanced and emerging economies. Bank of England, Working Paper no. 522.

[16] Chen, Y., Rogoff, K., 2003. Commodity currencies. Journal of International Economics, 60(1), 133-160.

[17] Chiquier, L., Lea, M., 2009. Housing finance policy in emerging markets. Washington, D.C.: The International Bank for Reconstruction and Development/The World Bank.

[18] Ciarlone, A., 2012. House price cycles in emerging economies. Banca d'Italia, Working Paper no. 863.

[19] Edelstein, P., Kilian, L., 2009. How sensitive are consumer expenditures to retail energy prices? Journal of Monetary Economics, 56(6), 766-779.

[20] El-Gamal, M.A., Jaffe, A.M., 2010. Energy, financial contagion, and the dollar. Rice University, Department of Economics, and James A. Baker III Institute for Public Policy, Working Paper.

[21] El-Ramly, A., 2015. The seven ages of oil: Boom and bust, war and peace, growth and decline. PennEnergy, February 4. Available at: http://www.pennenergy.com/articles/pennenergy/2015/02/the-sevenages-of-oil-boom-and-bust-war-and-peace-growth-and-decline.html.

[22] Frankel, J.A., 2014. Effects of speculation and interest rates in a carry trade model of commodity prices. Journal of International Money and Finance, 42(C), 88-112. 
[23] Groneworld, N., 2015. OIL: Can crude's boom-bust cycle be stopped? E\&EE Publishing, March 30. Available at: http://www.eenews.net/stories/1060015939.

[24] Hamilton, J.D., 1996. This is what happened to the oil price macroeconomy relationship. Journal of Monetary Economics, 38(2), 215-220.

[25] Hamilton, J.D., 2003. What is an oil shock? Journal of Econometrics, 113(2), 363-398.

[26] Hamilton, J.D., 2005. Oil and the macroeconomy. Prepared for: Palgrave Dictionary of Economics.

[27] Hamilton, J.D., 2009. Causes and consequences of the oil shock of 2007-08. Brookings Papers on Economic Activity, 40(1), 215-283.

[28] Hamilton, J.D., 2011. Nonlinearities and the macroeconomic effects of oil prices. Macroeconomic Dynamics, 15(S3), 364-378.

[29] Hammoudeh, S., Nguyen, D., Sousa, R.M., 2015. US monetary policy and sector commodity prices. Journal of International Money and Finance, 57, 61-85.

[30] Hammoudeh, S., Yuan, Y., 2008. Metal volatility in presence of oil and interest rate shocks. Energy Economics, 30, 606-620.

[31] Higgins, M., Klitgaard, T., Lerman, R., 2006. Recycling petrodollars. Federal Reserve Bank of New York, Current Issues in Economics and Finance, 12(9).

[32] Igan, D., Loungani, P., 2012. Global housing cycles. International Monetary Fund, IMF Working Paper no. 217.

[33] Jawadi, F., Mallick, S.K., Sousa, R.M., 2016. Fiscal and monetary policies in the BRICs: A panel VAR approach. Economic Modelling, 58, 535-542.

[34] Kaufmann, R.K., Gonzalez, N., Nickerson, T.A., Nesbit, T.S., 2011. Do household energy expenditures affect mortgage delinquency rates? Energy Economics, 33(2), 188-194.

[35] Leamer, E.E., 2007. Housing is the business cycle. Federal Reserve Bank of Kansas City, Proceedings, 149-233.

[36] Leung, C.K.Y., Shi, S., Tang, E., 2013. Commodity house prices. Federal Reserve Bank of Dallas, Globalization and Monetary Policy Institute, Working Paper No. 154.

[37] Narayan, P.K., Sharma, S.S., 2011. New evidence on oil price and firm returns. Journal of Banking and Finance, 35, 3253-3262.

[38] Prentice, R., Gloeckler, L., 1978. Regression analysis of grouped survival data with application to the breast cancer data. Biometrics, 34, 57-67.

[39] Quigley, J.M., 1984. The production of housing services and the derived demand for residential energy. The RAND Journal of Economics, 15(4), 555-567. 
[40] Park, J., Ratti, R.A., 2008. Oil price shocks and stock markets in the U.S. and 13 European countries. Energy Economics, 30, 2587-2608.

[41] Ratti, R.A., Vespignani, J.L., 2013. Why crude oil prices are high when global activity is weak? Economics Letters, 121(1), 133-136.

[42] Ratti, R.A., Vespignani, J.L., 2015. Commodity prices and BRIC and G3 liquidity: A SFAVEC approach. Journal of Banking and Finance, 53, 18-33.

[43] Sadorsky, P., 1999. Oil price shocks and stock market activity. Energy Economics, 21, 449-469.

[44] Sichel, D., 1991. Business cycle duration dependence: A parametric approach. Review of Economics and Statistics, 73(2), 254-260.

[45] Sousa, R.M., Vivian, A., Wohar, M.E. (2016). Predicting asset returns in the BRICs: The role of macroeconomic and fundamental predictors. International Review of Economics and Finance, 41, 122143 .

[46] Spencer, T., Chancel, L., Guérin, E., 2012. Exiting the EU crises in the right direction: towards a sustainable economy for all. IDDRI Working Paper No. 9.

[47] Swan, L., Ugursal, V.I., 2009. Modeling of end-use energy consumption in the residential sector: a review of modeling techniques. Renewable and Sustainable Energy Reviews, 13(8), 1819-1835.

[48] Taylor, J.B., 2007. Housing and monetary policy. Housing, housing finance and monetary policy. Federal Reserve Bank of Kansas City, Jackson Hole Symposium, 463-476.

[49] Young, A., 2013. US housing market: Following 15 years of boom-and-bust, is it getting back to normal? International Business Times. Available at: http://www.ibtimes.com/us-housing-market-following-15years-boom-bust-it-getting-back-normal-1110774.

[50] Zellner, A., 1990. Some properties of the duration of economic expansions and contractions. American Economist, 34, 20-27. 


\section{Appendix}

\section{A List of Tables}

Table 1: Continuous-time (Weibull) model.

\begin{tabular}{lcccc}
\hline \hline & $(1)$ & $(2)$ & $(3)$ & $(4)$ \\
\hline \hline$p$ & $2.007^{+, c}$ & $2.084^{+, c}$ & $2.008^{+, c}$ & $2.083^{+, c}$ \\
& $(0.144)$ & $(0.165)$ & $(0.145)$ & $(0.165)$ \\
Event & & $-0.596^{* * *}$ & & $-0.591^{* * *}$ \\
& & $(0.204)$ & & $(0.203)$ \\
Prev & & -0.028 & & -0.029 \\
& & $(0.361)$ & & $(0.360)$ \\
DurPrev & & -0.008 & & -0.008 \\
& & $(0.008)$ & & $(0.008)$ \\
European & -0.293 & 0.003 & -0.297 & -0.006 \\
& $(0.357)$ & $(0.525)$ & $(0.354)$ & $(0.517)$ \\
OilImpF & -0.049 & 0.079 & & \\
& $(0.324)$ & $(0.329)$ & & \\
OilImpC & & & -0.099 & 0.006 \\
& & & $(0.432)$ & $(0.414)$ \\
Constant & $-6.625^{* * *}$ & $-5.465^{* * *}$ & $-6.587^{* * *}$ & $-5.412^{* * *}$ \\
& $(0.566)$ & $(0.698)$ & $(0.581)$ & $(0.702)$ \\
\hline LogL & -36.75 & -33.2 & -36.73 & -33.2 \\
AIC & 81.50 & 80.3 & 81.45 & 80.4 \\
SBIC & 88.64 & 92.7 & 88.59 & 92.7 \\
LRI & - & - & - & - \\
Observ. & 44 & 43 & 44 & 43 \\
Ended & - & - & - & - \\
\hline \hline
\end{tabular}

Notes: Robust standard errors (clustered by country) for the estimated coefficients are in parentheses. Significance level at which the null hypothesis is rejected: ${ }^{* *}, 1 \% ;{ }^{* *}, 5 \%$; and ${ }^{*}, 10 \%$. The sign "+" indicates that $p$ is significantly higher than 1 using a $5 \%$ one-sided test with robust standard errors; $d, c$ and $i$, indicate the presence of decreasing, constant or increasing positive duration dependence at a $5 \%$ level, respectively. $A I C=2[-\log L+k]$ and $S B I C=2[-\log L+(k / 2) \log N]$, where $\log L$ is the $\log$-likelihood for the estimated model, $k$ is the number of regressors and $N$ is the number of observations. $L R I$ is the likelihood ratio index or pseudo- $R^{2}\left(L R I=1-\log L / \log L_{0}\right.$, where $L_{0}$ is the likelihood of the model without regressors). "Ended" indicates de number of non-zero observations in the Cloglog model, which also corresponds to the number of housing booms. The economic variables are lagged one period in order to avoid simultaneity problems and to account for the usual delays in the reporting of economic data. Columns (1)-(4) present the results of a continuous-time Weibull model. 
Table 2: Discrete-time Cloglog model that is analogue to the continuous-time Weibull model for housing booms.

\begin{tabular}{|c|c|c|c|c|c|}
\hline & $(1)$ & $(2)$ & $(3)$ & $(4)$ & $(5)$ \\
\hline$\overline{p p}$ & $\begin{array}{c}2.348^{+, c} \\
(0.487)\end{array}$ & $\begin{array}{c}2.382^{+, c} \\
(0.485)\end{array}$ & $\begin{array}{c}2.384^{+, c} \\
(0.483)\end{array}$ & $\begin{array}{c}2.828^{+, i} \\
(0.412)\end{array}$ & $\begin{array}{c}2.815^{+, i} \\
(0.396)\end{array}$ \\
\hline$G D P$ & $\begin{array}{l}-0.098 \\
(0.102)\end{array}$ & $\begin{array}{l}-0.107 \\
(0.096)\end{array}$ & $\begin{array}{l}-0.110 \\
(0.098)\end{array}$ & $\begin{array}{l}-0.116 \\
(0.154)\end{array}$ & $\begin{array}{l}-0.135 \\
(0.127)\end{array}$ \\
\hline Cred & $\begin{array}{c}0.009 \\
(0.011)\end{array}$ & $\begin{array}{c}0.009 \\
(0.011)\end{array}$ & $\begin{array}{c}0.009 \\
(0.010)\end{array}$ & $\begin{array}{c}0.002 \\
(0.023)\end{array}$ & $\begin{array}{c}0.013 \\
(0.014)\end{array}$ \\
\hline LendIR & $\begin{array}{c}0.360^{* * *} \\
(0.086)\end{array}$ & $\begin{array}{c}0.367^{* * *} \\
(0.087)\end{array}$ & $\begin{array}{c}0.366^{* * *} \\
(0.087)\end{array}$ & $\begin{array}{c}0.426^{* * *} \\
(0.090)\end{array}$ & $\begin{array}{c}0.414^{* * * *} \\
(0.086)\end{array}$ \\
\hline European & $\begin{array}{l}-0.490 \\
(0.390)\end{array}$ & $\begin{array}{l}-0.498 \\
(0.396)\end{array}$ & $\begin{array}{l}-0.487 \\
(0.401)\end{array}$ & $\begin{array}{c}-0.682^{* *} \\
(0.333)\end{array}$ & $\begin{array}{c}-0.671^{*} \\
(0.350)\end{array}$ \\
\hline NetExp & $\begin{array}{l}-0.017 \\
(0.049)\end{array}$ & & & & \\
\hline OilImpF & & $\begin{array}{c}0.045 \\
(0.442)\end{array}$ & & & \\
\hline OilImpC & & & $\begin{array}{c}0.123 \\
(0.420)\end{array}$ & & \\
\hline OilPr & & & & $\begin{array}{c}0.042^{* * *} \\
(0.008)\end{array}$ & \\
\hline WOilPr & & & & & $\begin{array}{c}0.037^{* * *} \\
(0.007)\end{array}$ \\
\hline Constant & $\begin{array}{c}-13.004^{* * *} \\
(2.285)\end{array}$ & $\begin{array}{c}-13.182^{* * *} \\
(2.251)\end{array}$ & $\begin{array}{c}-13.251^{* * *} \\
(2.249)\end{array}$ & $\begin{array}{c}13.430^{* * *} \\
(2.222) \\
\end{array}$ & $\begin{array}{c}13.092^{* * *} \\
(2.149)\end{array}$ \\
\hline $\log L$ & -134.3 & -136.5 & -136.4 & -112.0 & -128.8 \\
\hline$A I C$ & 282.5 & 287.0 & 286.9 & 238.0 & 271.6 \\
\hline$S B I C$ & 317.2 & 321.8 & 321.7 & 272.3 & 306.4 \\
\hline$L R I$ & 0.193 & 0.200 & 0.200 & 0.260 & 0.245 \\
\hline Observ. & 1040 & 1069 & 1069 & 991 & 1069 \\
\hline Ended & 39 & 40 & 40 & 35 & 40 \\
\hline
\end{tabular}

Notes: Robust standard errors (clustered by country) for the estimated coefficients are in parentheses. Significance level at which the null hypothesis is rejected: ${ }^{* *}, 1 \%$; ${ }^{* *}, 5 \%$; and ${ }^{*}, 10 \%$. The sign "+" indicates that $p$ is significantly higher than 1 using a $5 \%$ one-sided test with robust standard errors; $d, c$ and $i$, indicate the presence of decreasing, constant or increasing positive duration dependence at a $5 \%$ level, respectively. $A I C=2[-\log L+k]$ and $S B I C=2[-\log L+(k / 2) \log N]$, where $\log L$ is the $\log$-likelihood for the estimated model, $k$ is the number of regressors and $N$ is the number of observations. $L R I$ is the likelihood ratio index or pseudo- $R^{2}\left(L R I=1-\log L / \log L_{0}\right.$, where $L_{0}$ is the likelihood of the model without regressors). "Ended" indicates de number of non-zero observations in the Cloglog model, which also corresponds to the number of housing booms. The economic variables are lagged one period in order to avoid simultaneity problems and to account for the usual delays in the reporting of economic data. Columns (1)-(5) show the results of a discrete-time Cloglog model that is analogue to the continuous-time Weibull model. 
Table 3: Cloglog regressions that are performed using natural cubic splines of the hazard functions for housing booms.

\begin{tabular}{|c|c|c|c|c|c|}
\hline & $(1)$ & $\overline{(2)}$ & $(3)$ & $(4)$ & $(5)$ \\
\hline$\overline{\overline{S p l i n e} 1}$ & $\begin{array}{c}0.209^{* * *} \\
(0.037)\end{array}$ & $\begin{array}{c}0.213^{* * *} \\
(0.036)\end{array}$ & $\begin{array}{c}0.213^{* * *} \\
(0.036)\end{array}$ & $\begin{array}{c}0.216^{* * *} \\
(0.044)\end{array}$ & $\begin{array}{c}0.218^{* * *} \\
(0.039)\end{array}$ \\
\hline Spline2 & $\begin{array}{c}-0.251^{* * *} \\
(0.088)\end{array}$ & $\begin{array}{c}-0.259^{* * *} \\
(0.084)\end{array}$ & $\begin{array}{c}-0.258^{* * *} \\
(0.084)\end{array}$ & $\begin{array}{c}-0.322^{* * *} \\
(0.104)\end{array}$ & $\begin{array}{c}-0.343^{* * *} \\
(0.093)\end{array}$ \\
\hline Spline 3 & $\begin{array}{l}1.085^{* *} \\
(0.486)\end{array}$ & $\begin{array}{l}1.125^{* *} \\
(0.464)\end{array}$ & $\begin{array}{l}1.117^{* *} \\
(0.464)\end{array}$ & $\begin{array}{c}1.381^{* * *} \\
(0.532)\end{array}$ & $\begin{array}{c}1.509^{* * *} \\
(0.487)\end{array}$ \\
\hline$G D P$ & $\begin{array}{l}-0.097 \\
(0.104)\end{array}$ & $\begin{array}{l}-0.106 \\
(0.097)\end{array}$ & $\begin{array}{l}-0.109 \\
(0.099)\end{array}$ & $\begin{array}{l}-0.109 \\
(0.154)\end{array}$ & $\begin{array}{l}-0.122 \\
(0.129)\end{array}$ \\
\hline Cred & $\begin{array}{c}0.008 \\
(0.012)\end{array}$ & $\begin{array}{c}0.007 \\
(0.011)\end{array}$ & $\begin{array}{c}0.008 \\
(0.011)\end{array}$ & $\begin{array}{c}0.002 \\
(0.019)\end{array}$ & $\begin{array}{c}0.012 \\
(0.012)\end{array}$ \\
\hline LendIR & $\begin{array}{c}0.362^{* * *} \\
(0.092)\end{array}$ & $\begin{array}{c}0.369^{* * *} \\
(0.093)\end{array}$ & $\begin{array}{c}0.368^{* * * *} \\
(0.093)\end{array}$ & $\begin{array}{c}0.425^{* * *} \\
(0.091)\end{array}$ & $\begin{array}{c}0.408^{* * *} \\
(0.089)\end{array}$ \\
\hline European & $\begin{array}{l}-0.527 \\
(0.390)\end{array}$ & $\begin{array}{l}-0.535 \\
(0.389)\end{array}$ & $\begin{array}{l}-0.522 \\
(0.396)\end{array}$ & $\begin{array}{l}-0.495 \\
(0.407)\end{array}$ & $\begin{array}{l}-0.493 \\
(0.416)\end{array}$ \\
\hline NetExp & $\begin{array}{l}-0.015 \\
(0.043)\end{array}$ & & & & \\
\hline OilImpF & & $\begin{array}{l}0.021 \\
(0.412)\end{array}$ & & & \\
\hline OilImpC & & & $\begin{array}{c}0.114 \\
(0.390)\end{array}$ & & \\
\hline OilPr & & & & $\underset{(0.009)}{0.045^{* * *}}$ & \\
\hline WOilPr & & & & & $\begin{array}{c}0.042^{* * *} \\
(0.009)\end{array}$ \\
\hline Constant & $\begin{array}{c}-9.779^{* * *} \\
(1.490)\end{array}$ & $\begin{array}{c}-9.903^{* * *} \\
(1.503)\end{array}$ & $\begin{array}{c}-9.982^{* * *} \\
(1.506)\end{array}$ & $\begin{array}{c}-11.851^{* * *} \\
(1.694)\end{array}$ & $\begin{array}{c}-11.539^{* * *} \\
(1.629)\end{array}$ \\
\hline $\log L$ & -134.7 & -136.9 & -136.8 & -112.3 & -128.8 \\
\hline$A I C$ & 287.3 & 291.8 & 291.7 & 242.5 & 275.6 \\
\hline$S B I C$ & 331.9 & 336.5 & 336.4 & 286.6 & 320.4 \\
\hline$L R I$ & 0.190 & 0.198 & 0.198 & 0.259 & 0.245 \\
\hline Observ. & 1040 & 1069 & 1069 & 991 & 1069 \\
\hline Ended & 39 & 40 & 40 & 35 & 40 \\
\hline
\end{tabular}

Notes: Robust standard errors (clustered by country) for the estimated coefficients are in parentheses. Significance level at which the null hypothesis is rejected: ${ }^{* *}, 1 \% ;{ }^{* *}, 5 \%$; and ${ }^{*}, 10 \%$. The sign " + " indicates that $p$ is significantly higher than 1 using a $5 \%$ one-sided test with robust standard errors; $d, c$ and $i$, indicate the presence of decreasing, constant or increasing positive duration dependence at a $5 \%$ level, respectively. $A I C=2[-\log L+k]$ and $S B I C=2[-\log L+(k / 2) \log N]$, where $\log L$ is the $\log$-likelihood for the estimated model, $k$ is the number of regressors and $N$ is the number of observations. $L R I$ is the likelihood ratio index or pseudo- $R^{2}\left(L R I=1-\log L / \log L_{0}\right.$, where $L_{0}$ is the likelihood of the model without regressors). "Ended" indicates de number of non-zero observations in the Cloglog model, which also corresponds to the number of housing booms. The economic variables are lagged one period in order to avoid simultaneity problems and to account for the usual delays in the reporting of economic data. Columns (1)-(5) report the Cloglog regressions that are performed using natural cubic splines of the hazard functions, with knots at periods $1,30,45$ and 68. 
Table 4: Continuous-time (Weibull) model for housing busts.

\begin{tabular}{lcccc}
\hline \hline & $(1)$ & $(2)$ & $(3)$ & $(4)$ \\
\hline \hline$p$ & $2.267^{+, c}$ & $2.935^{+, i}$ & $2.239^{+, c}$ & $2.881^{+, c}$ \\
& $(0.273)$ & $(0.480)$ & $(0.253)$ & $(0.545)$ \\
Event & & -0.687 & & -0.566 \\
& & $(0.624)$ & & $(0.653)$ \\
Prev & & $0.827^{*}$ & & $0.896^{*}$ \\
& & $(0.485)$ & & $(0.488)$ \\
DurPrev & & -0.035 & & -0.041 \\
& & $(0.036)$ & & $(0.031)$ \\
European & 1.501 & 1.441 & 1.528 & 1.375 \\
& $(1.093)$ & $(0.995)$ & $(1.079)$ & $(0.920)$ \\
OilImpF & $-1.443^{* * *}$ & $-1.452^{* *}$ & & \\
& $(0.340)$ & $(0.615)$ & & \\
OilImpC & & & $-1.543^{* * *}$ & $-1.625^{* * *}$ \\
& & & $(0.435)$ & $(0.507)$ \\
Constant & $-7.738^{* * *}$ & $-8.577^{* * *}$ & $-7.522^{* * *}$ & $-8.376^{* * *}$ \\
& $(1.705)$ & $(2.272)$ & $(1.684)$ & $(2.432)$ \\
\hline LogL & -19.47 & -15.0 & -19.63 & -15.0 \\
AIC & 46.94 & 44.1 & 47.25 & 44.0 \\
SBIC & 52.12 & 53.1 & 52.43 & 53.1 \\
LRI & - & - & - & - \\
Observ. & 27 & 27 & 27 & 27 \\
Ended & - & - & - & - \\
\hline \hline
\end{tabular}

Notes: Robust standard errors (clustered by country) for the estimated coefficients are in parentheses. Significance level at which the null hypothesis is rejected: ${ }^{* *}, 1 \% ;{ }^{* *}, 5 \%$; and ${ }^{*}, 10 \%$. The sign "+" indicates that $p$ is significantly higher than 1 using a $5 \%$ one-sided test with robust standard errors; $d, c$ and $i$, indicate the presence of decreasing, constant or increasing positive duration dependence at a $5 \%$ level, respectively. $A I C=2[-\log L+k]$ and $S B I C=2[-\log L+(k / 2) \log N]$, where $\log L$ is the $\log$-likelihood for the estimated model, $k$ is the number of regressors and $N$ is the number of observations. $L R I$ is the likelihood ratio index or pseudo- $R^{2}\left(L R I=1-\log L / \log L_{0}\right.$, where $L_{0}$ is the likelihood of the model without regressors). "Ended" indicates de number of non-zero observations in the Cloglog model, which also corresponds to the number of housing busts. The economic variables are lagged one period in order to avoid simultaneity problems and to account for the usual delays in the reporting of economic data. Columns (1)-(4) present the results of a continuous-time Weibull model. 
Table 5: Discrete-time Cloglog model that is analogue to the continuous-time Weibull model for housing busts.

\begin{tabular}{|c|c|c|c|c|c|}
\hline & $(1)$ & $(2)$ & $(3)$ & $(4)$ & $(5)$ \\
\hline$p$ & $\begin{array}{c}2.210^{+, c} \\
(0.357)\end{array}$ & $\begin{array}{c}2.411^{+, c} \\
(0.341)\end{array}$ & $\begin{array}{c}2.462^{+, c} \\
(0.321)\end{array}$ & $\begin{array}{c}2.508^{+, c} \\
(0.619)\end{array}$ & $\begin{array}{c}2.577^{+, c} \\
0.566\end{array}$ \\
\hline$G D P$ & $\begin{array}{l}0.360^{*} \\
(0.190)\end{array}$ & $\begin{array}{l}0.305^{*} \\
(0.167)\end{array}$ & $\begin{array}{l}0.287^{*} \\
(0.155)\end{array}$ & $\begin{array}{l}0.357^{*} \\
(0.187)\end{array}$ & $\begin{array}{l}0.354^{*} \\
(0.183)\end{array}$ \\
\hline Cred & $\begin{array}{l}-0.088 \\
(0.072)\end{array}$ & $\begin{array}{l}-0.044 \\
(0.081)\end{array}$ & $\begin{array}{l}-0.041 \\
(0.086)\end{array}$ & $\begin{array}{l}-0.074 \\
(0.072)\end{array}$ & $\begin{array}{l}-0.066 \\
(0.072)\end{array}$ \\
\hline LendIR & $\begin{array}{c}0.118^{* *} \\
(0.059)\end{array}$ & $\begin{array}{c}0.100 \\
(0.063)\end{array}$ & $\begin{array}{l}0.117^{* *} \\
(0.054)\end{array}$ & $\begin{array}{l}0.117^{*} \\
(0.062)\end{array}$ & $\begin{array}{l}0.118^{*} \\
(0.060)\end{array}$ \\
\hline European & $\begin{array}{l}1.146 \\
(1.277)\end{array}$ & $\begin{array}{c}1.259 \\
(1.299)\end{array}$ & $\begin{array}{c}1.167 \\
(1.328)\end{array}$ & $\begin{array}{c}1.055 \\
(1.168)\end{array}$ & $\begin{array}{c}1.191 \\
(1.119)\end{array}$ \\
\hline NetExp & $\begin{array}{l}-0.002 \\
(0.028)\end{array}$ & & & & \\
\hline OilImpF & & $\begin{array}{c}-0.965^{* *} \\
(0.395)\end{array}$ & & & \\
\hline OilImpC & & & $\begin{array}{c}-1.259^{* *} \\
(0.595)\end{array}$ & & \\
\hline OilPr & & & & $\begin{array}{l}-0.018 \\
(0.016)\end{array}$ & \\
\hline WOilPr & & & & & $\begin{array}{l}-0.020 \\
(0.015)\end{array}$ \\
\hline Constant & $\begin{array}{c}-9.011^{* * *} \\
(1.698) \\
\end{array}$ & $\begin{array}{c}-8.718^{* * *} \\
(1.907)\end{array}$ & $\begin{array}{c}-8.668^{* * *} \\
(1.903) \\
\end{array}$ & $\begin{array}{c}-9.263^{* * *} \\
(0.016) \\
\end{array}$ & $\begin{array}{c}-9.504^{* * *} \\
(2.075) \\
\end{array}$ \\
\hline $\log L$ & -67.9 & -70.4 & -69.6 & -67.0 & -70.5 \\
\hline$A I C$ & 149.9 & 154.8 & 153.9 & 148.0 & 155.0 \\
\hline$S B I C$ & 179.9 & 185.2 & 184.2 & 177.8 & 185.4 \\
\hline$L R I$ & 0.141 & 0.153 & 0.159 & 0.144 & 0.152 \\
\hline Observ. & 544 & 565 & 565 & 521 & 565 \\
\hline Ended & 18 & 19 & 19 & 18 & 19 \\
\hline
\end{tabular}

Notes: Robust standard errors (clustered by country) for the estimated coefficients are in parentheses. Significance level at which the null hypothesis is rejected: ${ }^{* *}, 1 \%$; ${ }^{* *}, 5 \%$; and ${ }^{*}, 10 \%$. The sign "+" indicates that $p$ is significantly higher than 1 using a $5 \%$ one-sided test with robust standard errors; $d, c$ and $i$, indicate the presence of decreasing, constant or increasing positive duration dependence at a $5 \%$ level, respectively. $A I C=2[-\log L+k]$ and $S B I C=2[-\log L+(k / 2) \log N]$, where $\log L$ is the $\log$-likelihood for the estimated model, $k$ is the number of regressors and $N$ is the number of observations. $L R I$ is the likelihood ratio index or pseudo- $R^{2}\left(L R I=1-\log L / \log L_{0}\right.$, where $L_{0}$ is the likelihood of the model without regressors). "Ended" indicates de number of non-zero observations in the Cloglog model, which also corresponds to the number of housing busts. The economic variables are lagged one period in order to avoid simultaneity problems and to account for the usual delays in the reporting of economic data. Columns (1)-(5) show the results of a discrete-time Cloglog model that is analogue to the continuous-time Weibull model. 
Table 6: Cloglog regressions that are performed using natural cubic splines of the hazard functions for housing busts.

\begin{tabular}{lccccc}
\hline \hline & $(1)$ & $(2)$ & $(3)$ & $(4)$ & $(5)$ \\
\hline \hline Spline 1 & $0.213^{* * *}$ & $0.247^{* * *}$ & $0.251^{* * *}$ & $0.218^{* * *}$ & $0.228^{* * *}$ \\
& $(0.069)$ & $(0.067)$ & $(0.066)$ & $(0.069)$ & $(0.064)$ \\
Spline 2 & $-0.594^{* *}$ & $-0.666^{* * *}$ & $-0.673^{* * *}$ & $-0.595^{* * *}$ & $-0.638^{* * *}$ \\
& $(0.234)$ & $(0.228)$ & $(0.228)$ & $(0.219)$ & $(0.211)$ \\
Spline 3 & $2.163^{* *}$ & $2.376^{* *}$ & $2.407^{* *}$ & $2.126^{* *}$ & $2.322^{* *}$ \\
& $(0.990)$ & $(0.966)$ & $(0.973)$ & $(0.956)$ & $(0.925)$ \\
GDP & $0.359^{*}$ & $0.297^{*}$ & $0.289^{*}$ & $0.369^{* *}$ & $0.364^{* *}$ \\
& $(0.185)$ & $(0.159)$ & $(0.147)$ & $(0.182)$ & $(0.178)$ \\
Cred & -0.093 & -0.050 & -0.053 & -0.088 & -0.080 \\
& $(0.064)$ & $(0.074)$ & $(0.074)$ & $(0.069)$ & $(0.070)$ \\
LendIR & $0.114^{* *}$ & $0.096^{*}$ & $0.111^{* *}$ & $0.115^{* *}$ & $0.114^{* *}$ \\
& $(0.055)$ & $(0.059)$ & $(0.049)$ & $(0.056)$ & $(0.055)$ \\
European & 0.897 & 0.873 & 0.823 & 0.809 & 0.917 \\
& $(0.961)$ & $(0.936)$ & $(0.954)$ & $(0.971)$ & $(0.946)$ \\
NetExp & -0.007 & & & & \\
OilImpF & $(0.028)$ & & & & \\
OilImpC & & $-1.092^{* * *}$ & & & \\
OilPr & & $(0.413)$ & $-1.367^{* *}$ & & \\
WOilPr & & & $(0.637)$ & 0.000 & \\
Constant & $-8.385^{* * *}$ & $-7.846^{* * *}$ & $-7.714^{* * *}$ & $-8.463^{* * *}$ & $-8.706^{* * *}$ \\
& $(1.612)$ & $(1.842)$ & $(1.876)$ & $(1.741)$ & $(1.630)$ \\
\hline LogL & -66.0 & -67.9 & -67.4 & -65.8 & -69.2 \\
AIC & 150.0 & 153.7 & 152.8 & 149.6 & 156.4 \\
SBIC & 188.7 & 192.8 & 191.8 & 187.7 & 195.5 \\
LRI & 0.165 & 0.184 & 0.189 & 0.159 & 0.167 \\
Observ. & 544 & 565 & 565 & 521 & 565 \\
Ended & 18 & 19 & 19 & 18 & 19 \\
\hline \hline & & & & & \\
\hline
\end{tabular}

Notes: Robust standard errors (clustered by country) for the estimated coefficients are in parentheses. Significance level at which the null hypothesis is rejected: ${ }^{* *}, 1 \%$; ${ }^{* *}, 5 \%$; and ${ }^{*}, 10 \%$. The sign " + indicates that $p$ is significantly higher than 1 using a $5 \%$ one-sided test with robust standard errors; $d, c$ and $i$, indicate the presence of decreasing, constant or increasing positive duration dependence at a $5 \%$ level, respectively. $A I C=2[-\log L+k]$ and $S B I C=2[-\log L+(k / 2) \log N]$, where $\log L$ is the $\log$-likelihood for the estimated model, $k$ is the number of regressors and $N$ is the number of observations. $L R I$ is the likelihood ratio index or pseudo- $R^{2}\left(L R I=1-\log L / \log L_{0}\right.$, where $L_{0}$ is the likelihood of the model without regressors). "Ended" indicates de number of non-zero observations in the Cloglog model, which also corresponds to the number of housing busts. The economic variables are lagged one period in order to avoid simultaneity problems and to account for the usual delays in the reporting of economic data. Columns (1)-(5) report the Cloglog regressions that are performed using natural cubic splines of the hazard functions, with knots at periods $1,30,45$ and 85. 
Table 7: Continuous-time (Weibull) model for normal times.

\begin{tabular}{lcccc}
\hline \hline & $(1)$ & $(2)$ & $(3)$ & $(4)$ \\
\hline \hline$p$ & $1.316^{+, d}$ & $1.576^{+, d}$ & $1.317^{+, d}$ & $1.559^{+, d}$ \\
Event & $(0.144)$ & $(0.190)$ & $(0.144)$ & $(0.199)$ \\
& & -0.161 & & -0.114 \\
Prev & & $(0.283)$ & & $(0.265)$ \\
& & -0.318 & & -0.345 \\
DurPrev & & $(0.478)$ & & $(0.483)$ \\
& & -0.031 & & $-0.033^{*}$ \\
European & $0.795^{* *}$ & $(0.019)$ & & $(0.019)$ \\
& $(0.383)$ & $(0.462)$ & $(0.387)$ & $(0.441)$ \\
OilImpF & 0.029 & -0.369 & & \\
& $(0.298)$ & $(0.362)$ & & -0.034 \\
OilImpC & & & 0.069 & $(0.426)$ \\
Constant & $-4.864^{* * *}$ & $-4.066^{* * *}$ & $-4.895^{* * *}$ & $-4.274^{* * *}$ \\
& $(0.517)$ & $(0.970)$ & $(0.553)$ & $(1.044)$ \\
\hline LogL & -55.21 & -43.0 & -55.20 & -43.2 \\
AIC & 118.42 & 100.0 & 118.39 & 100.5 \\
SBIC & 125.73 & 112.1 & 125.71 & 112.6 \\
LRI & - & - & - & - \\
Observ. & 46 & 42 & 46 & 42 \\
Ended & - & - & - & - \\
\hline \hline
\end{tabular}

Notes: Robust standard errors (clustered by country) for the estimated coefficients are in parentheses. Significance level at which the null hypothesis is rejected: *** $1 \%$; ${ }^{* *}, 5 \%$; and ${ }^{*}, 10 \%$. The sign "+" indicates that $p$ is significantly higher than 1 using a $5 \%$ one-sided test with robust standard errors; $d, c$ and $i$, indicate the presence of decreasing, constant or increasing positive duration dependence at a $5 \%$ level, respectively. $A I C=2[-\log L+k]$ and $S B I C=2[-\log L+(k / 2) \log N]$, where $\log L$ is the $\log$-likelihood for the estimated model, $k$ is the number of regressors and $N$ is the number of observations. $L R I$ is the likelihood ratio index or pseudo- $R^{2}\left(L R I=1-\log L / \log L_{0}\right.$, where $L_{0}$ is the likelihood of the model without regressors). "Ended" indicates de number of non-zero observations in the Cloglog model, which also corresponds to the number of normal time spells. The economic variables are lagged one period in order to avoid simultaneity problems and to account for the usual delays in the reporting of economic data. Columns (1)-(4) present the results of a continuous-time Weibull model. 
Table 8: Discrete-time Cloglog model that is analogue to the continuous-time Weibull model for normal times.

\begin{tabular}{|c|c|c|c|c|c|}
\hline & $(1)$ & $(2)$ & $(3)$ & $(4)$ & $(5)$ \\
\hline$p$ & $\begin{array}{c}1.290^{+, d} \\
(0.152)\end{array}$ & $\begin{array}{c}1.295^{+, d} \\
(0.143)\end{array}$ & $\begin{array}{c}1.299^{+, d} \\
(0.144)\end{array}$ & $\begin{array}{c}1.337^{+, d} \\
(0.151)\end{array}$ & $\begin{array}{c}1.290^{+, d} \\
(0.137)\end{array}$ \\
\hline$G D P$ & $\begin{array}{c}0.380^{* * *} \\
(0.130)\end{array}$ & $\begin{array}{c}0.337^{* * *} \\
(0.104)\end{array}$ & $\begin{array}{c}0.341^{* * *} \\
(0.081)\end{array}$ & $\begin{array}{c}0.309^{* * *} \\
(0.099)\end{array}$ & $\begin{array}{c}0.335^{* * *} \\
(0.092)\end{array}$ \\
\hline Cred & $\begin{array}{c}0.007 \\
(0.016)\end{array}$ & $\begin{array}{c}0.009 \\
(0.013)\end{array}$ & $\begin{array}{c}0.008 \\
(0.014)\end{array}$ & $\begin{array}{c}0.009 \\
(0.013)\end{array}$ & $\begin{array}{c}0.009 \\
(0.013)\end{array}$ \\
\hline LendIR & $\begin{array}{c}0.102^{* * *} \\
(0.034)\end{array}$ & $\begin{array}{c}0.088^{* * *} \\
(0.033)\end{array}$ & $\begin{array}{c}0.087^{* * *} \\
(0.034)\end{array}$ & $\begin{array}{c}0.045 \\
(0.037)\end{array}$ & $\begin{array}{c}0.037 \\
(0.038)\end{array}$ \\
\hline European & $\begin{array}{c}1.222^{* * * *} \\
(0.463)\end{array}$ & $\begin{array}{c}1.097^{* * *} \\
(0.404)\end{array}$ & $\begin{array}{c}1.103^{* * *} \\
(0.400)\end{array}$ & $\begin{array}{c}1.235^{* * *} \\
(0.422)\end{array}$ & $\begin{array}{c}1.175^{* * *} \\
(0.404)\end{array}$ \\
\hline NetExp & $\begin{array}{l}-0.024 \\
(0.040)\end{array}$ & & & & \\
\hline OilImpF & & $\begin{array}{l}-0.201 \\
(0.293)\end{array}$ & & & \\
\hline OilImpC & & & $\begin{array}{l}-0.180 \\
(0.301)\end{array}$ & & \\
\hline OilPr & & & & $\begin{array}{c}-0.015^{*} \\
(0.009)\end{array}$ & \\
\hline WOilPr & & & & & $\begin{array}{c}-0.020^{* *} \\
(0.009)\end{array}$ \\
\hline Constant & $\begin{array}{c}-5.750^{* * *} \\
(0.799)\end{array}$ & $\begin{array}{c}-5.360^{* * *} \\
(0.686)\end{array}$ & $\begin{array}{c}-5.391^{* * *} \\
(0.667)\end{array}$ & $\begin{array}{c}-4.780^{* * *} \\
(0.807)\end{array}$ & $\begin{array}{c}-4.335^{* * *} \\
(0.831)\end{array}$ \\
\hline $\log L$ & -111.2 & -116.0 & -116.0 & -108.3 & -113.5 \\
\hline$A I C$ & 236.5 & 246.0 & 246.0 & 230.5 & 241.1 \\
\hline$S B I C$ & 268.0 & 277.5 & 277.5 & 261.9 & 272.6 \\
\hline$L R I$ & 0.081 & 0.073 & 0.073 & 0.087 & 0.093 \\
\hline Observ. & 639 & 663 & 663 & 653 & 663 \\
\hline Ended & 30 & 31 & 31 & 29 & 31 \\
\hline
\end{tabular}

Notes: Robust standard errors (clustered by country) for the estimated coefficients are in parentheses. Significance level at which the null hypothesis is rejected: ${ }^{* *}, 1 \%$; ${ }^{* *}, 5 \%$; and ${ }^{*}, 10 \%$. The sign " + " indicates that $p$ is significantly higher than 1 using a $5 \%$ one-sided test with robust standard errors; $d, c$ and $i$, indicate the presence of decreasing, constant or increasing positive duration dependence at a $5 \%$ level, respectively. $A I C=2[-\log L+k]$ and $S B I C=2[-\log L+(k / 2) \log N]$, where $\log L$ is the $\log$-likelihood for the estimated model, $k$ is the number of regressors and $N$ is the number of observations. $L R I$ is the likelihood ratio index or pseudo- $R^{2}\left(L R I=1-\log L / \log L_{0}\right.$, where $L_{0}$ is the likelihood of the model without regressors). "Ended" indicates de number of non-zero observations in the Cloglog model, which also corresponds to the number of normal time spells. The economic variables are lagged one period in order to avoid simultaneity problems and to account for the usual delays in the reporting of economic data. Columns (1)-(5) show the results of a discrete-time Cloglog model that is analogue to the continuous-time Weibull model. 
Table 9: Cloglog regressions that are performed using natural cubic splines of the hazard functions for normal times.

\begin{tabular}{lccccc}
\hline \hline & $(1)$ & $(2)$ & $(3)$ & $(4)$ & $(5)$ \\
\hline \hline Spline 1 & $0.054^{*}$ & $0.061^{* *}$ & $0.064^{* *}$ & $0.066^{* *}$ & $0.058^{* *}$ \\
& $(0.031)$ & $(0.030)$ & $(0.033)$ & $(0.031)$ & $(0.029)$ \\
Spline 2 & -0.302 & $-0.334^{*}$ & $-0.353^{*}$ & $-0.323^{*}$ & -0.299 \\
& $(0.196)$ & $(0.187)$ & $(0.199)$ & $(0.191)$ & $(0.187)$ \\
Spline 3 & 1.176 & $1.293^{*}$ & $1.361^{*}$ & 1.186 & 1.107 \\
& $(0.753)$ & $(0.717)$ & $(0.759)$ & $(0.736)$ & $(0.729)$ \\
GDP & $0.355^{* * *}$ & $0.330^{* * *}$ & $0.335^{* * *}$ & $0.307^{* * *}$ & $0.331^{* * *}$ \\
& $(0.136)$ & $(0.110)$ & $(0.110)$ & $(0.101)$ & $(0.092)$ \\
Cred & 0.003 & 0.005 & 0.004 & 0.005 & 0.005 \\
& $(0.016)$ & $(0.014)$ & $(0.014)$ & $(0.014)$ & $(0.013)$ \\
LendIR & $0.122^{* * *}$ & $0.112^{* * *}$ & $0.112^{* * *}$ & 0.059 & 0.051 \\
& $(0.039)$ & $(0.039)$ & $(0.038)$ & $(0.046)$ & $(0.047)$ \\
European & $1.114^{* * *}$ & $1.076^{* * *}$ & $1.080^{* * *}$ & $1.102^{* * *}$ & $1.025^{* * *}$ \\
& $(0.424)$ & $(0.363)$ & $(0.376)$ & $(0.375)$ & $(0.366)$ \\
NetExp & 0.008 & & & & \\
OilImpF & $(0.042)$ & $-0.432^{*}$ & & & \\
OilImpC & & $(0.248)$ & & & \\
& & & -0.453 & & \\
OilPr & & & & & \\
WOilPr & & & & & \\
Constant & $-5.619^{* * *}$ & $-5.246^{* * *}$ & $-5.272^{* * *}$ & $-4.642^{* * *}$ & $-4.189^{* * *}$ \\
& $(0.679)$ & $(0.609)$ & $(0.626)$ & $(0.837)$ & $(0.878)$ \\
\hline LogL & -110.5 & -114.9 & -114.8 & -107.4 & -112.7 \\
AIC & 238.9 & 247.8 & 247.7 & 232.8 & 243.5 \\
SBIC & 279.1 & 288.3 & 288.2 & 273.1 & 284.0 \\
LRI & 0.088 & 0.082 & 0.083 & 0.095 & 0.100 \\
Observ. & 639 & 663 & 663 & 653 & 663 \\
Ended & 30 & 31 & 31 & 29 & 31 \\
\hline \hline
\end{tabular}

Notes: Robust standard errors (clustered by country) for the estimated coefficients are in parentheses. Significance level at which the null hypothesis is rejected: ${ }^{* *}, 1 \%$; ${ }^{* *}, 5 \%$; and ${ }^{*}, 10 \%$. The sign " + " indicates that $p$ is significantly higher than 1 using a $5 \%$ one-sided test with robust standard errors; $d, c$ and $i$, indicate the presence of decreasing, constant or increasing positive duration dependence at a $5 \%$ level, respectively. $A I C=2[-\log L+k]$ and $S B I C=2[-\log L+(k / 2) \log N]$, where $\log L$ is the log-likelihood for the estimated model, $k$ is the number of regressors and $N$ is the number of observations. $L R I$ is the likelihood ratio index or pseudo- $R^{2}\left(L R I=1-\log L / \log L_{0}\right.$, where $L_{0}$ is the likelihood of the model without regressors). "Ended" indicates de number of non-zero observations in the Cloglog model, which also corresponds to the number of normal time spells. The economic variables are lagged one period in order to avoid simultaneity problems and to account for the usual delays in the reporting of economic data. Columns (1)-(5) report the Cloglog regressions that are performed using natural cubic splines of the hazard functions, with knots at periods $1,35,60$ and 107. 
B List of Figures 


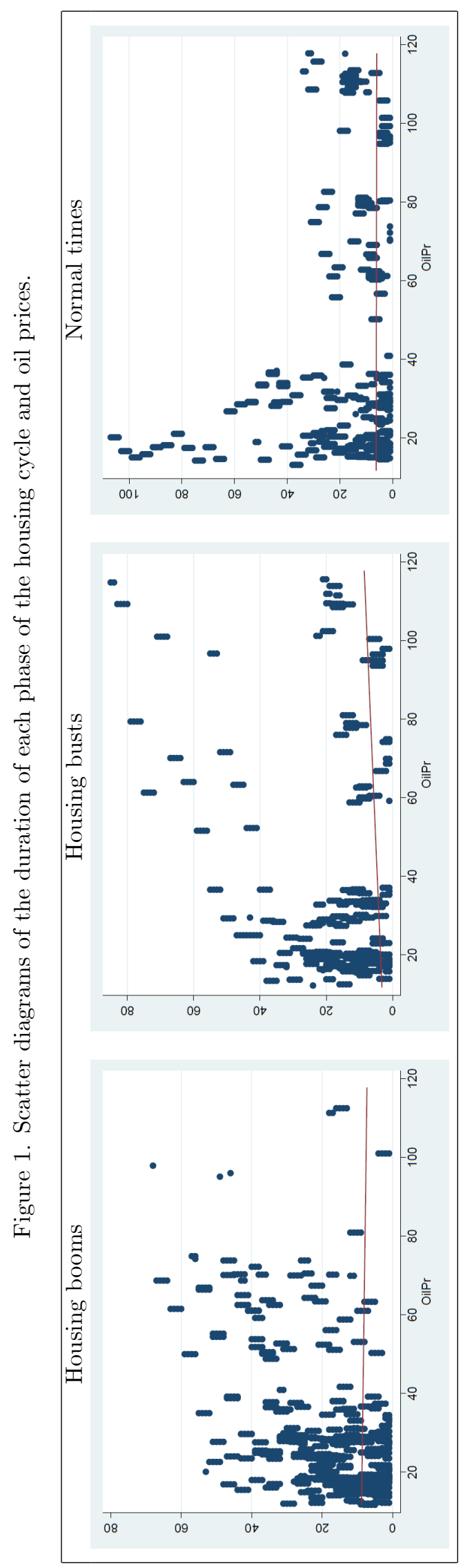


Figure 2. Non-parametric estimates for the hazard rates and survival functions.

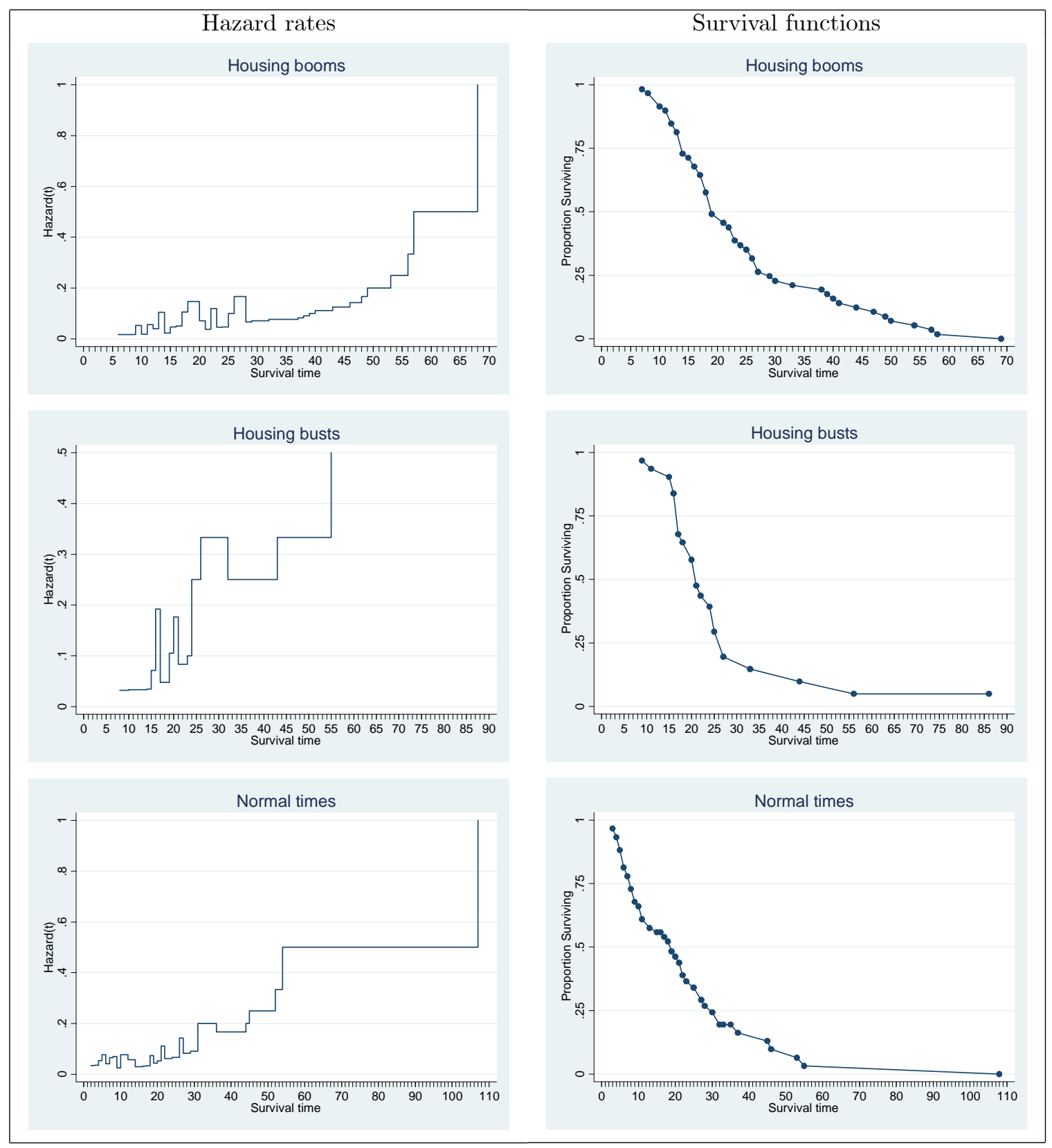

